\title{
COMPARISON OF SYMMETRIC AND ASYMMETRIC STEEL DIAGRID STRUCTURES BY NON-LINEAR STATIC ANALYSIS
}

\author{
Prashant T G ${ }^{1}$, Shrithi S Badami ${ }^{2}$, Avinash Gornale ${ }^{3}$ \\ ${ }^{I}$ P.G student, Department of Civil Engineering, Adichunchanagiri Institute of Technology, Chikkamagaluru, Karnataka, \\ India \\ ${ }^{2}$ Assistant Professor, Department of Civil Engineering, Adichunchanagiri Institute of Technology, Chikkamagaluru, \\ Karnataka, India \\ ${ }^{3}$ Assistant Professor, Department of Civil Engineering, Maharaja Institute of Technology, Mysore, Karnataka, India
}

\begin{abstract}
Diagonalized grid structures - "diagrids" - have emerged as one of the most innovative and adaptable approaches to structuring buildings in this millennium. Diagrid is a particular form of space truss, it consists of perimeter grid made up of a series of triangulated truss system. Diagrid is formed by intersecting the diagonal and horizontal components.

Construction of multi - storey building is rapidly increasing throughout the world. Advance in construction technology, materials, structural systems, various analysis and design software have facilitated the growth of various kinds of buildings. Diagrid buildings are emerging as structurally efficient as well as architecturally and aesthetically significant assemblies for tall buildings. Recently these diagrid structural systems have been widely used for tall buildings due to the structural efficiency and aesthetic potential provided by the unique geometric configuration of the system. This paper presents a 12 storey steel diagrid structure which is $36 \mathrm{~m}$ in height. Symmetric and asymmetric structural configurations of diagrid structures were modelled and analyzed using SAP 2000 by considering Dead load, Live load and Seismic Loads (IS 1893-Part-1, 2002). Then FEMA 356 hinges (auto hinges) are assigned to the same structure and Nonlinear Static (Pushover) analysis is carried out by using seismic load as the pushover load case to find out the performance points that is Immediate Occupancy, Life Safety, and Collapse Prevention of diagrid elements using static pushover curve. At the same time spectral displacement demand \& spectral displacement capacity as well as spectral acceleration demand and spectral acceleration capacity is compared to know the adequacy of the design by using ATC capacity spectrum method.
\end{abstract}

Keywords: Diagrid, Pushover analysis, Spectral displacement demand, Spectral displacement capacity, Spectral acceleration demand, Spectral acceleration capacity

\section{INTRODUCTION}

The evolution of tall-building structural systems, based on new structural concepts with newly adopted high-strength materials and construction methods, has been towards 'stiffness' and 'lightness'. Structural systems nowadays are becoming stiffer and lighter. Diagrid, are known as a very light structure and one of the strongest when it comes to withstanding against lateral forces. The term "diagrid" is a combination of the words "diagonal" and "grid" and refers to a structural system that is single-thickness in nature and gains its structural integrity through the use of triangulation. The lighter a structure is, the higher it can rise. On the other hand, it is also easier to blow away a light object than a heavy one. Diagrid can save from $20 \%$ to $30 \%$ the amount of structural steel in high-rise buildings. Moreover, highstrength material technology has come a long way since the invention of modern high-rise buildings in 1930's, materials themselves are stronger and lighter.

Diagrid structures carry lateral wind loads much more efficiently due to their diagonal member's axial action compared to the conventional orthogonal structures for tall buildings such as framed tubes. Today's architects have been losing interest in aesthetic expressions provided by conventional braced tubes composed of orthogonal members and large diagonal members because they always seek something new and different.

\section{NONLINEAR STATIC (PUSHOVER)}

\section{ANALYSIS}

The use of the nonlinear static analysis came into practice in 1970 's but the potential of the pushover analysis has been recognized for last $10-15$ years. This procedure is mainly used to estimate the strength and drift capacity of existing structure and the seismic demand for the structure subjected to selected earthquake. This procedure can be used for checking the adequacy of new structural design as well.

Pushover analysis is defined as an analysis where a mathematical model directly incorporating the nonlinear load-deformation characteristics of individual components and elements of the structure shall be subjected to monotonically increasing lateral loads representing inertia 
forces in an earthquake until a "target displacement" is exceeded. Target displacement is the maximum displacement (elastic plus inelastic) of the structure at top expected under selected earthquake ground motion. Nonlinear Static (Pushover) analysis is conducted to find out the performance points that is Immediate Occupancy, Life Safety, and Collapse Prevention of diagrid elements using static pushover curve.

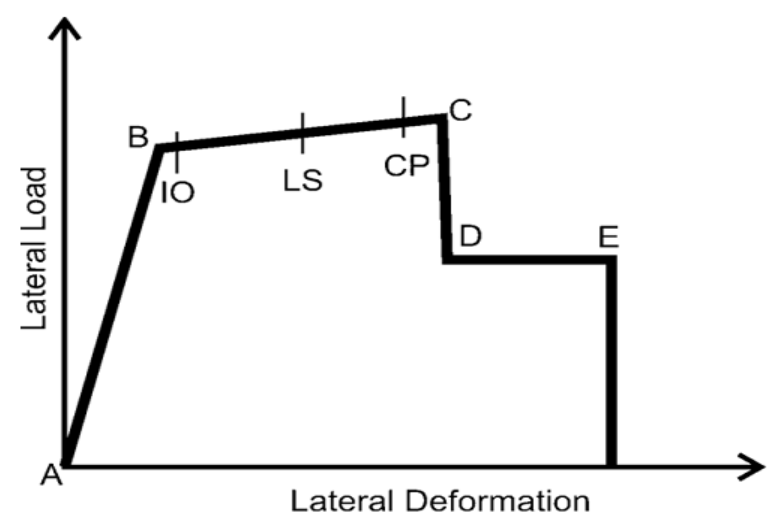

Fig.1: Static pushover curve

Response characteristics that can be obtained from the pushover analysis are summarised as follows:

a) Estimates force and displacement capacities of the structure and sequence of the member yielding and the progress of the overall capacity curve.

b) Estimates force (axial, shear and moment) demands on potentially brittle elements and deformation demands on ductile elements.

c) Estimates global displacement demand, corresponding inter-storey drifts and damages on structural and nonstructural elements expected under the earthquake ground motion considered.

d) Sequences of the failure of elements and the consequent effect on the overall structural stability.

e) Identification of the critical regions, where the inelastic deformations are expected to be high and identification of strength irregularities (in plan or in elevation) of the building.

\section{NEED FOR NON-LINEAR STATIC (PUSHOVER) ANALYSIS}

Conventionally, seismic assessment and design has relied on linear or equivalent linear (with reduced stiffness) analysis of structural systems. In this approach, simple models are used for various elements of the structure, which are subjected to seismic forces evaluated from elastic or design spectra, and reduced by force reduction (or behaviour) factors. This ensures displacements are amplified to account for the reduction of applied forces. The reduced forceamplified deformation linear elastic approach fails to fit within the principle of failure mode control, which is part of performance based assessment and design. This in turn has led to an increase in the use of inelastic analysis as a more realistic means of assessing deformational state in structures subjected to strong ground motions. The pushover analysis is a significant step forward by giving consideration to those inelastic response characteristics that will distinguish between good and bad performance in severe earthquakes. The non linear static pushover analysis is a partial and relatively simple immediate solution to the complex problem for predicting forces and deformation demands imposed on the structure and its elements due to ground motions. The pushover is a part of an evaluation process and provides estimates of demands imposed on structures and elements. Hence, there is always a need of a method which is rational and accurate and at the same time able to identify seismic deficiencies correctly and that too in a correct order of vulnerability. Pushover analysis is able to satisfy these criteria satisfactorily and in a convenient way.

\subsection{Capacity Spectrum Method (ATC 40)}

In this method the maximum inelastic deformation of a nonlinear SDOF system can be approximated from the maximum deformation of a linear elastic SDOF system with an equivalent period and damping. This procedure uses the estimates of ductility to calculate effective period and damping. This procedure uses the pushover curve in an acceleration-displacement response spectrum (ADRS) format. This can be obtained through simple conversion using the dynamic properties of the system. The pushover curve in an ADRS format is termed a "capacity spectrum" for the structure. The seismic ground motion is represented by a response spectrum in the same ADRS format and it is termed as demand spectrum which is as shown in Fig. 1. The equivalent period $\left(\mathrm{T}_{\text {eq }}\right)$ is computed from the initial period of vibration $\left(\mathrm{T}_{\mathrm{i}}\right)$ of the nonlinear system and displacement ductility ratio $(\mu)$. Similarly, the equivalent damping ratio $\left(\beta_{\mathrm{eq}}\right)$ is computed from initial damping ratio and the displacement ductility ratio $(\mu)$. ATC 40 provides the following equations to calculate equivalent time period $\left(\mathrm{T}_{\mathrm{eq}}\right)$ and equivalent damping $\left(\beta_{\mathrm{eq}}\right)$.

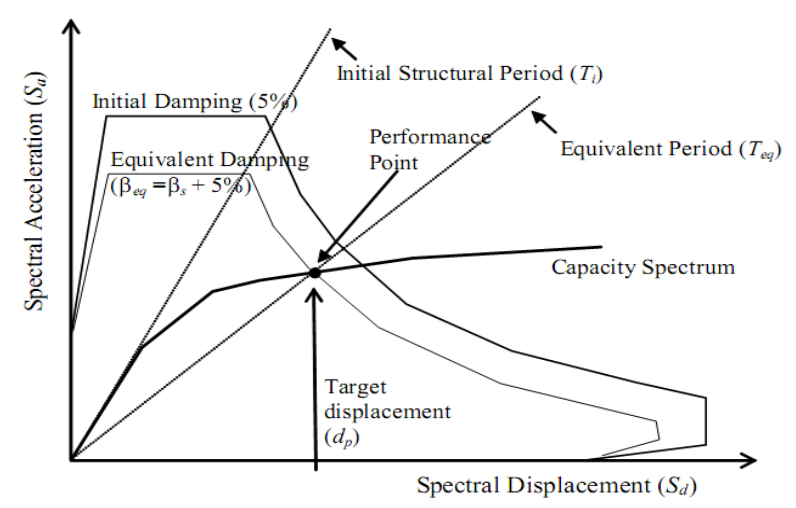

Fig-2: Schematic representation of Capacity Spectrum Method (ATC 40)

\section{PROBLEM DEFINITION}

This unit presents the details about dimensions of building, material used and type of analysis for the present study and are as mentioned in TABLE 1 . A 12 storey steel diagrid structure having height $36 \mathrm{~m}$ and lateral dimensions as $18 \mathrm{mX} 18 \mathrm{~m}$ is considered for the analysis. The dead load, live 
load and seismic loads and the default load combinations were considered for the analysis and the structure is modelled in SAP 2000 and Linear Analysis is conducted to get the maximum bending moment, shear force and axial force. Later the FEMA 356 Hinges were defined in the model and Nonlinear Static (Pushover) Analysis has been conducted using ATC-40 capacity spectrum method to calculate Base Shear, Displacements, Effective time, Spectral Displacement Capacity \& Spectral Displacement Demand and also Performance points of Diagrid Structure.

Table-1: Building Details Considered for analysis

\begin{tabular}{|l|l|l|}
\hline $\begin{array}{l}\text { Sl. } \\
\text { No }\end{array}$ & \multicolumn{2}{|l|}{ Building Details } \\
\hline 1 & Symmetric structure & Model-1 \\
\hline 2 & Asymmetric structure & Model-2 \\
\hline 3 & $\begin{array}{l}\text { Plan dimensions of } \\
\text { building }\end{array}$ & $18 \mathrm{~m} \mathrm{X} \mathrm{18m}$ \\
\hline 4 & Height of building & $36 \mathrm{~m}$ \\
\hline 5 & No. of stories & 12 \\
\hline 6 & Storey height & $3 \mathrm{~m}$ \\
\hline $\mathbf{7}$ & Type of structure & Steel diagrid structure \\
\hline $\mathbf{8}$ & Type of analysis & $\begin{array}{l}\text { Nonlinear } \\
\text { analysis }\end{array}$ \\
\hline
\end{tabular}

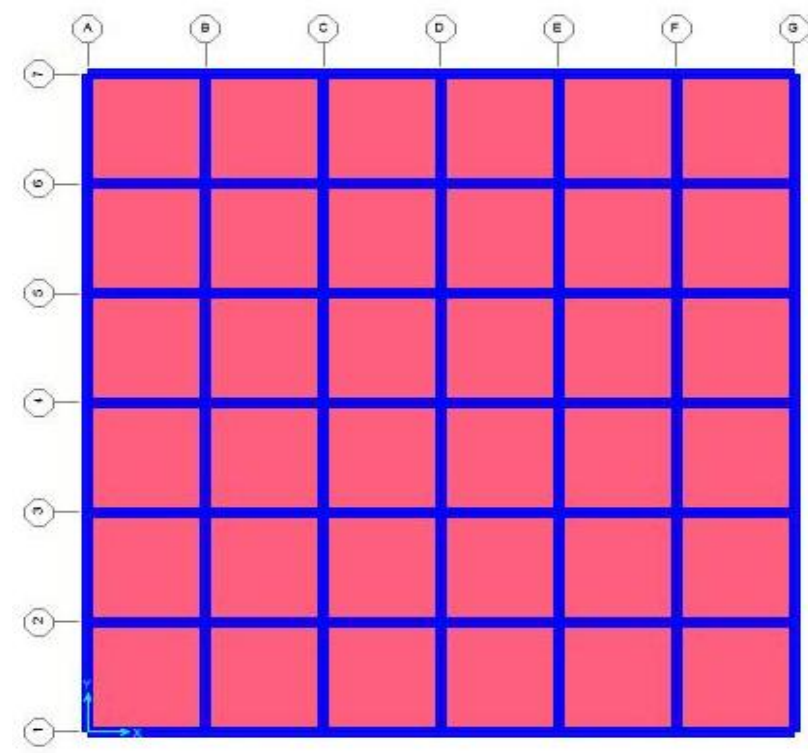

Fig-3: Plan of Diagrid Structure 18mx18m (Model-1)

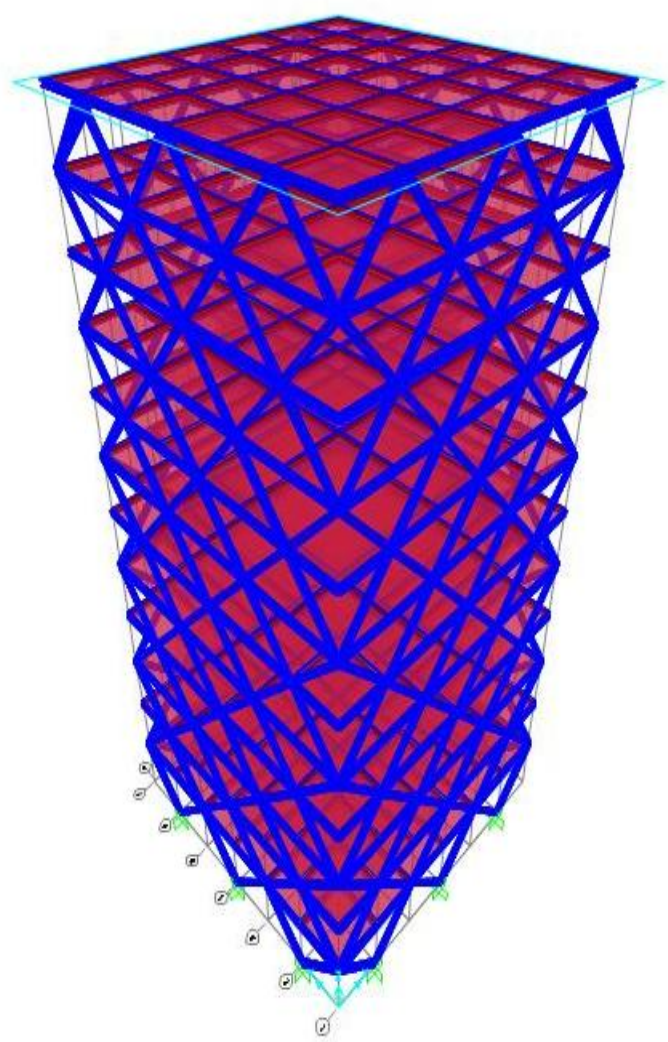

Fig-4: 3D Diagrid Building Model (Model-1) in SAP 2000

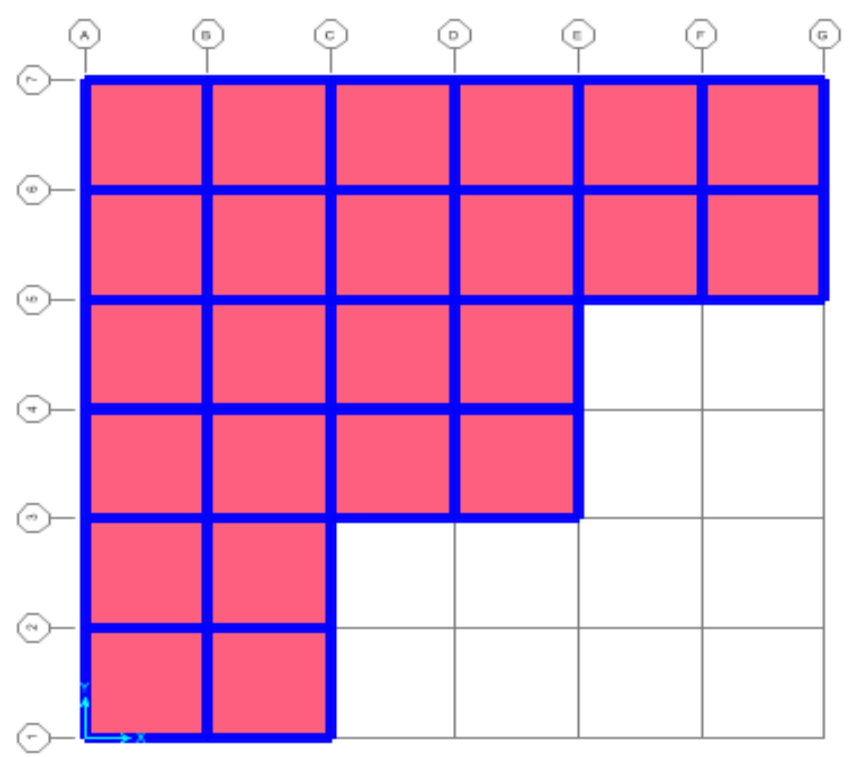

Fig-5: Plan of diagrid structure $18 \mathrm{~m} * 18 \mathrm{~m}$ (Model-2) 


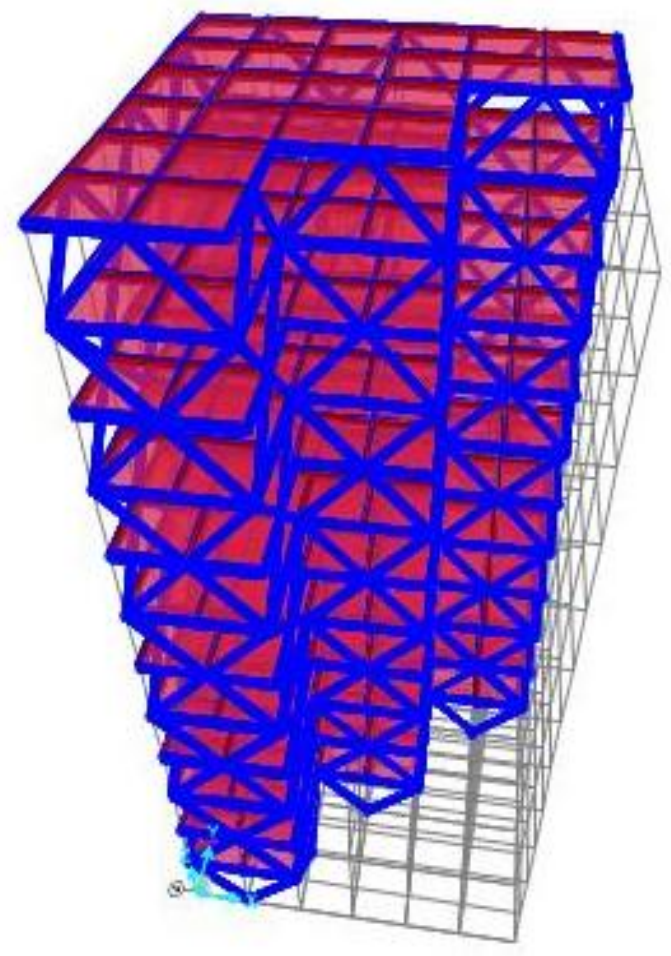

Fig-6: 3D diagrid building model (Model-2) in SAP2000

\section{RESULTS AND DISCUSSIONS}

The modelled building is analysed using Nonlinear Static (Pushover) analysis. This chapter presents Nonlinear Static (Pushover) analysis results and its discussions. Pushover analysis was performed first in a load control manner to apply all gravity loads on to the structure (gravity push), then a lateral pushover analysis in transverse direction was performed in a displacement control manner starting at the end of gravity push. The results obtained from this analysis are checked by comparing spectral displacement demand and spectral displacement capacity from the pushover curve.

\subsection{Nonlinear Static (Pushover) Analysis}

Nonlinear Static (Pushover) Analysis permits to identify critical members likely to reach limit states during the earthquake. Nonlinear Static Analysis is carried out after assigning flexural hinges (FEMA 356 Auto hinges) using ATC 40 Capacity Spectrum Method. Performance points \& levels (IO, LS, and CP) which were observed in different pushover steps for symmetric structure are as shown in Fig 7, Fig 8 and Fig 9 and for asymmetric structure are as shown in Fig 11, Fig 12 and Fig 13. Spectral Acceleration vs. Spectral Displacement Graph which is obtained from the analysis for symmetric structure is shown in Fig 10 and for asymmetric structure is shown in Fig 14. Spectral Displacement Demand \& Spectral Displacement Capacity which is calculated from Fig-10 and Fig 14 is shown in Chart-1.
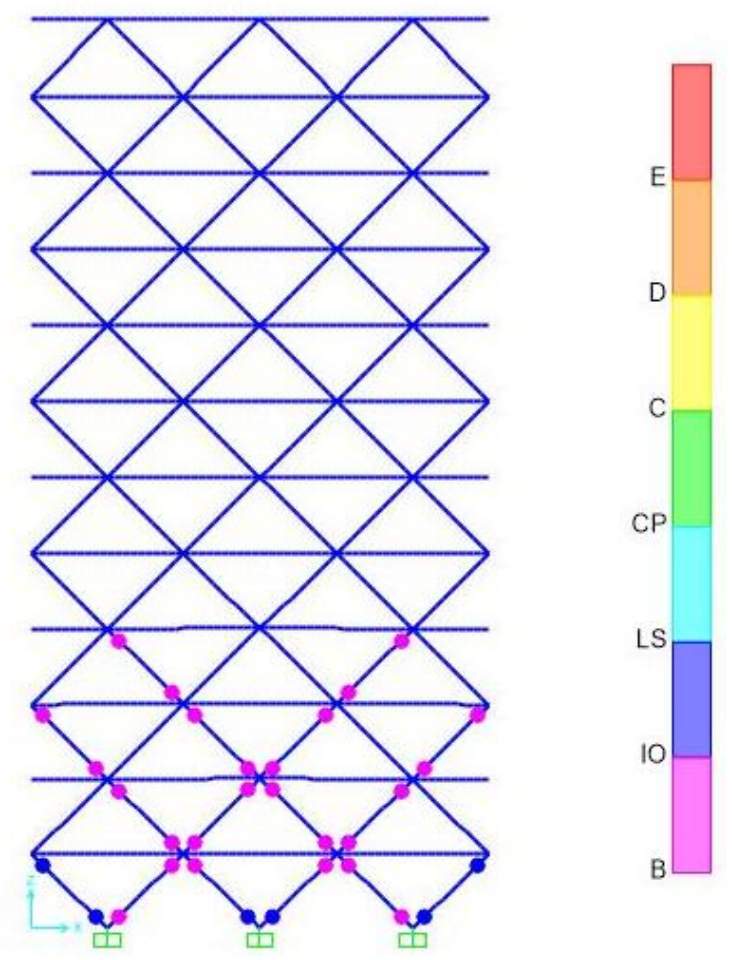

Fig-7: Pushover step -2 of Model-1
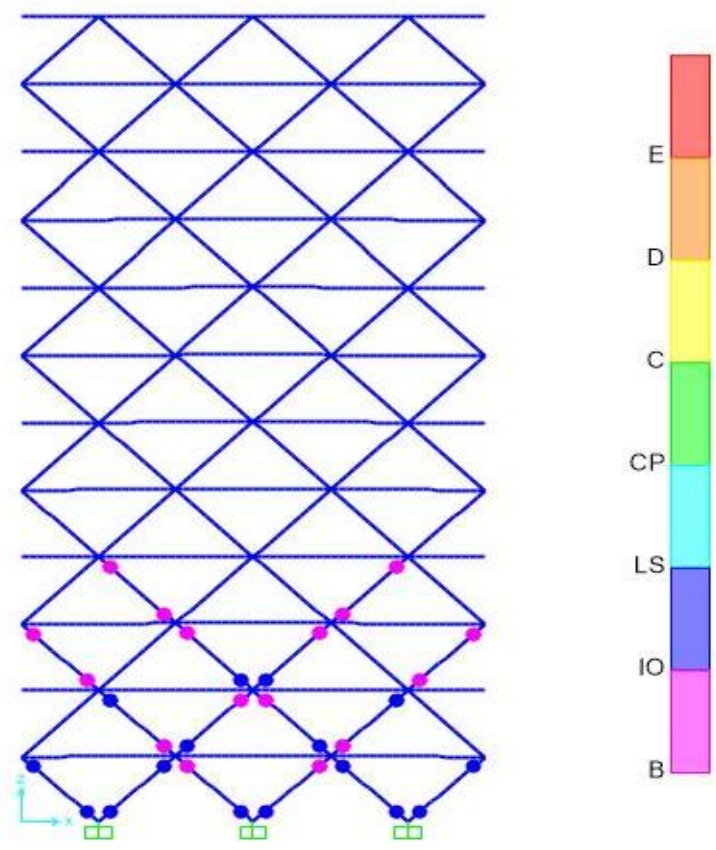

Fig-8: Pushover step -3 of Model-1 

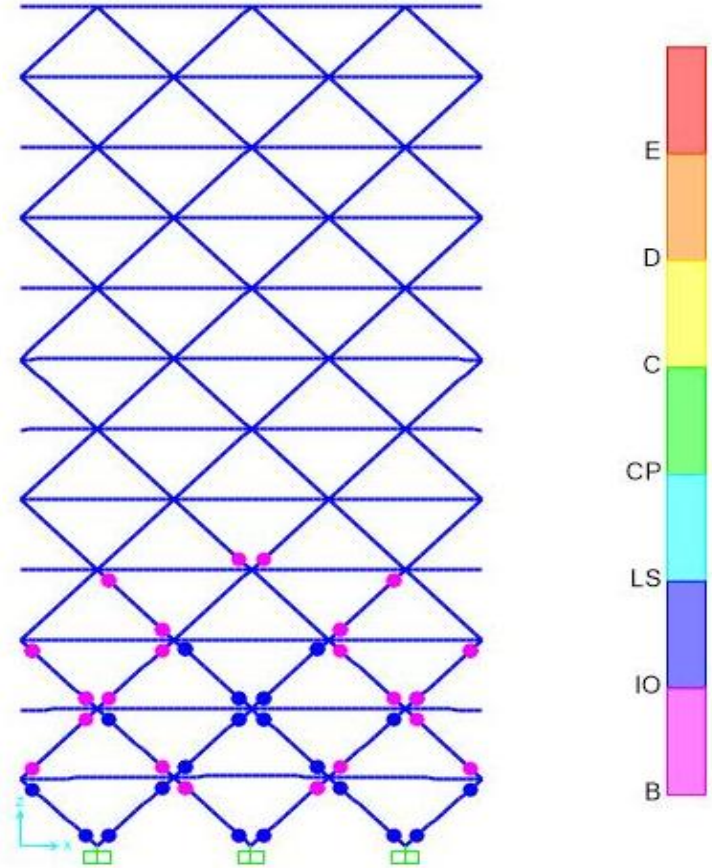

Fig-9: Pushover step -4 of Model-1

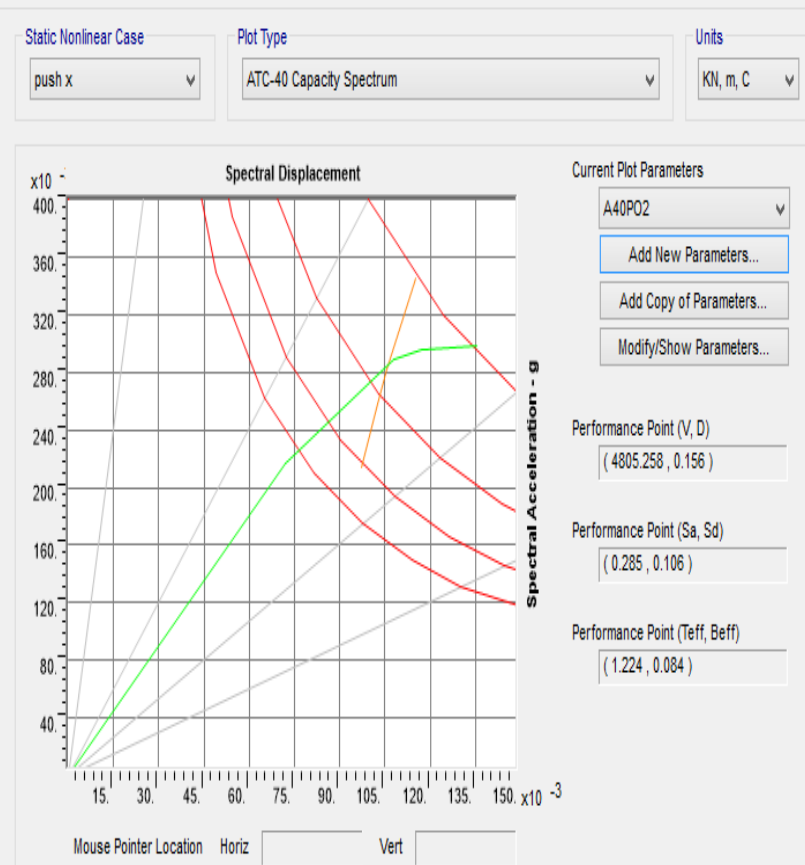

Fig-10: Pushover Demand Capacity Curve (ATC 40) of Model-1

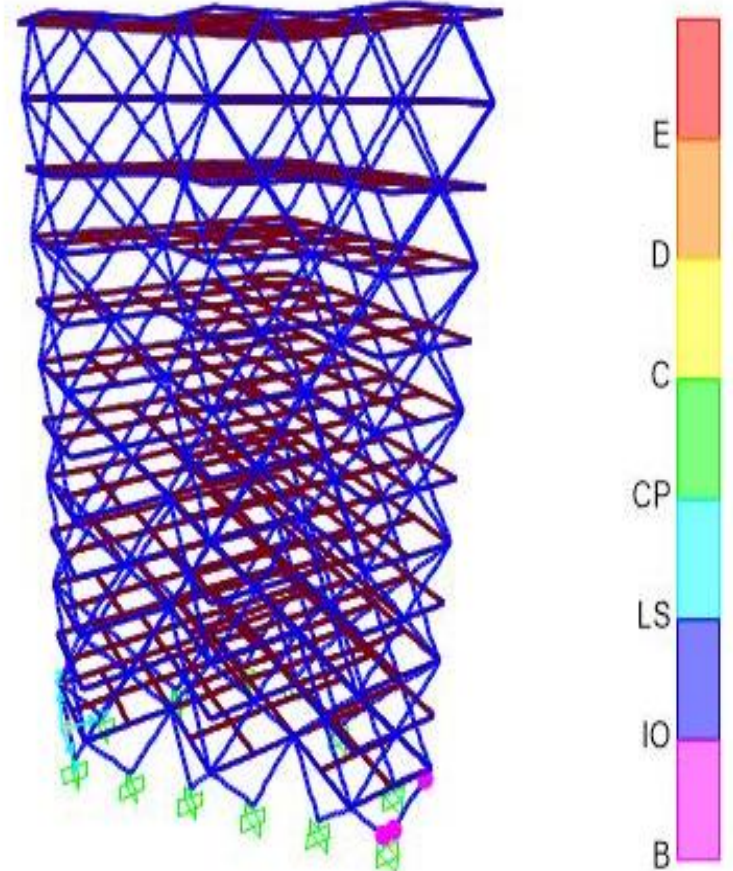

Fig-11: Pushover step-1 of Model-2
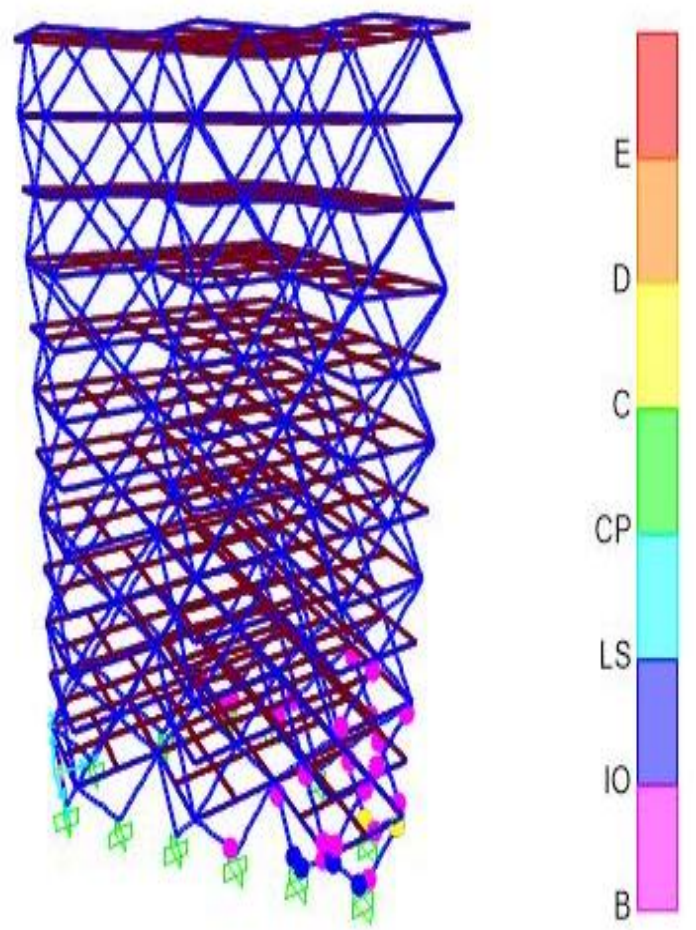

Fig-12: Pushover step-2 of Model-2 

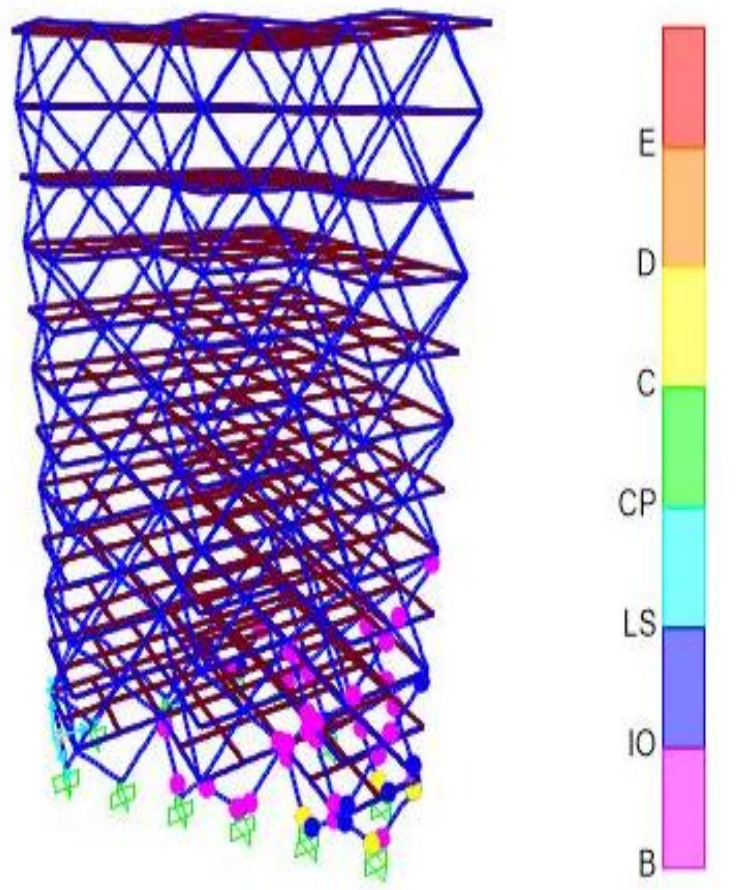

Fig-13: Pushover step-3 of Model-2

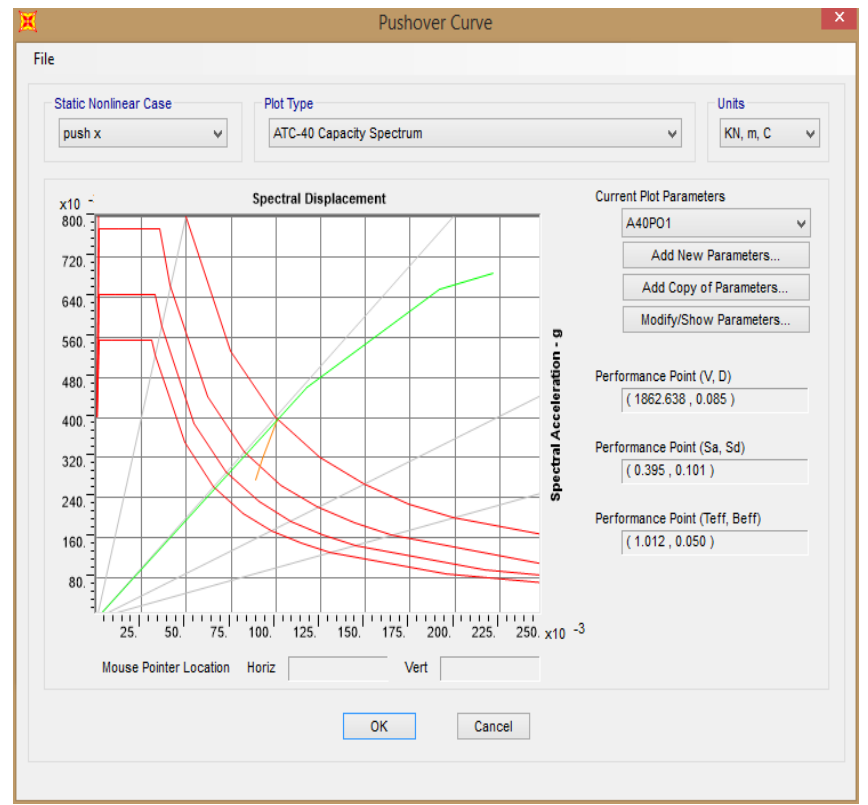

Fig-14: Pushover Demand Capacity Curve (ATC 40) of Model - 2

For symmetric structure it can be observed from Fig 7 that is pushover step 2 that the assigned hinges are in a state of immediate occupancy. In the next steps which are shown in Fig 8 and Fig 9 that is step 3 and step 4 one can observe that some hinges shifts from state of immediate occupancy to state of life safety due to the incremental increase in lateral load.

For asymmetric structure it can be observed from Fig 11 that is pushover step 1 that assigned hinges are in a state of immediate occupancy. In the next step which is shown in Fig 12 that is step 2 it can be observed that some hinges shifts from immediate occupancy state to state of life safety and from Fig 13 that is step 3 it can be seen that some hinges shifts from life safety to collapse state.

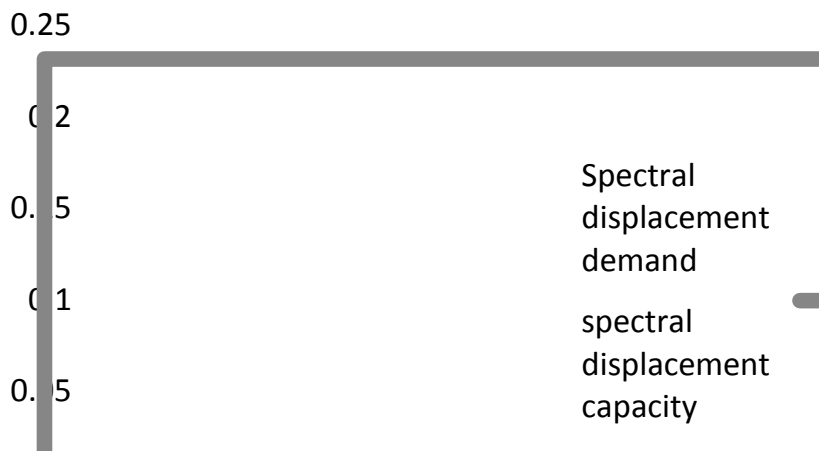

MODEL $1 \quad$ MODEL 2

Chart-1: Comparison between Capacity \& Demand

\section{CONCLUSION}

It can be concluded that from the pushover analysis one can know the state of the structure by observing changes in the hinge states.

From Chart-1 it can be observed that spectral displacement capacity of asymmetric structure is more than that of symmetric structure by $63 \%$ for the same height and plan area.

\section{ACKNOWLEDGMENTS}

The authors thank the Principal and Management of Adichunchanagiri Institute of Technology, Chikkamagaluru for the continued support and cooperation in carrying out this research study.

\section{REFERENCES}

[1] Rohit Kumar Singh, Dr. Vivek Garg, Dr. Abhay Sharma (2014), "Analysis and design of concrete diagrid building and its comparision with conventional frame building", IJSET, pp1330-1337, Vol 2, Issue 6, September 02, 2014.

[2] K. Moon (2009), "Design and construction of steel diagrid structures”, NSCC, pp 392-405, 2009.

[3] Kyoung-Sun Moon, Jerome J. Connor and John E. Fernandez(2007), "Diagrid structural systems for tall buildings- characteristics and methodology for preliminary design", Wiley interscience, pp 205 230,2007.

[4] J. Kim, Y. Jun and Y.-Ho Lee (2010), "Seismic Performance Evaluation of Diagrid System Buildings", $2^{\text {nd }}$ Specialty conference on disaster mitigation, pp 1-9, June 9-12, 2010.

[5] Ravi K Revankar and R.G.Talasadar (2014), "Pushover analysis of diagrid structure", International Journal of Engineering and Innovative 
Technology (IJEIT), pp168-174, Volume 4, Issue 3, September 2014.

[6] IS 1893 (Part 1): 2002 - Criteria for Earthquake resistant Design of structures.

[7] IS 800 - 1984 - Code of practice for General construction in steel.

[8] CSI Analysis Reference Manual for SAP 2000.

\section{BIOGRAPHIES}

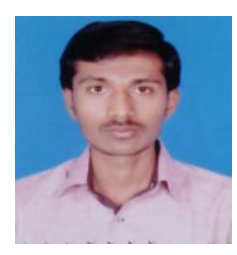

Prashant T G, is a Final Year PG Student, pursuing his Master of Technology in Structural Engineering from Adichunchanagiri Institute of Technology, Chikkamagaluru, Karnataka

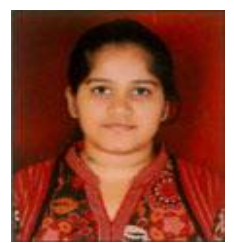

Shrithi S Badami, is working as a Assistant Professor in department of civil engineering in Adichunchanagiri Institute of Technology, Chikkamagaluru, Karnataka. Her areas of research interest include earthquake engineering, structural engineering and concrete technology.

Avinash Gornale is working as a Assistant Professor in department of civil engineering in Maharaja Institute of Technology, Mysore, Karnataka. His areas of research interest include earthquake engineering and concrete technology 